\title{
Factors Affecting Sesame Seed Exports in Burkina Faso: The Vector Error Correction Approach
}

\author{
Kafando Wendata Achille \\ Ministry of Agriculture-Burkina Faso, 03 BP 7005 Ouaga 2000, Burkina Faso \\ E-mail: achillekafando@gmail.com \\ Chia-Sheng Hsu \\ Division I, Taiwan Research Institute, 10F.-8, No. 2, Fuxing N. Rd., Songshan 105 Taipei, Taiwan \\ E-mail: victor9999951@hotmail.com \\ Ching-Cheng Chang \\ Institute of Economics, Academia Sinica, No. 128, Section 2, Academia Rd, Nankang 115 Taipei, Taiwan \\ E-mail: emily33662666@gmail.com \\ Shih-Hsun Hsu* \\ Department of Agricultural Economics, National Taiwan University \\ No. 1, Section 4, Roosevelt Rd, Taipei, 106-17, Taiwan \\ E-mail: m577@ntu.edu.tw
}

The research is financed by Academia Sinica, Taiwan. Grant No. AS-SS-107-02.

\begin{abstract}
Burkina Faso's (BFA) dependence on a single export crop, namely cotton, has so far threatened its economy since the fluctuating and uncontrollable drops in world cotton prices. The diversification of cash crops has become a national priority that is appropriated day by day by actors of rural development, and more particularly by farmers seeking to improve and secure their income. Thus, export crops, such as sesame, appear obvious and essential, not only for farmers' income security but also for the country by its ability to attract currencies. In the last decade, BFA's the sesame sector has recorded a tremendous growth both in quantity and value of exports to being the eighth world largest exporter of sesame seed. Considering its unequaled performance in the export of sesame seed, we deemed relevant to identify the key factors affecting that performance and to study their effects on sesame seed export earnings in order to draft appropriated policies aimed to enhance the country's earnings. This study uses the cointegration approach, and has purposely designed exports value as the independent variable to analyze the country exports performance using time series data for the period of 47 years (1970-2016). One cointegration vector is found between the variables employed; thereby the Vector Error Correction Model has been performed. The empirical results reveal that nominal exchange rate, producer price, world export volume of sesame seed as a proxy of world demand, and world price are key factors affecting significantly the country's exports performance in the short-run. Moreover, in the long-run nominal exchange rate, production, producer price, and world export price are factors determining significantly export earnings of sesame seed in Burkina Faso. For Burkina Faso to increase its market shares and export earnings, especially in the long-run, it is principally recommended to boost the production by increasing significantly yields and ensure an appropriate transmission of international prices increments to farmers.
\end{abstract}

Keywords: Agricultural Export, Determinants of Agricultural Exports, Sesame Seed, Cointegration, Burkina Faso.

DOI: $10.7176 / \mathrm{DCS} / 10-4-03$

Publication date: April $30^{\text {th }} 2020$

\section{Introduction}

Sesame seed represents an important export product for Sub-Saharan African countries (SSA). The seed is widely cultivated across the world; however, it constitutes a major cash crop for West and East African countries where the seed is produced in bulk (Food and Agriculture Organization (FAO), 2019). The major producers and exporters of sesame seed in SSA are Tanzania, Sudan, Ethiopia, Nigeria, and Burkina Faso (BFA) with their production representing 57\% worldwide according to data from FAO. As for all SSA countries, agriculture remains the engine of BFA's economy and contributes to $35-40 \%$ of the GDP (Gross Domestic Product) through exports (Brüntrup and Zimmermann, 2009).

Sesame seed is considered as the second major cash crop for export in BFA and the country is one of the world-leading producer and exporter. The sesame sector is relatively young in BFA; however, recently the sector has been characterized by a tremendous growth in production and export. The growth is driven by the increasing world demand, which principally comes from the sesame-oil industry and the confectionary sector. This steady 
increase in world demand of sesame seed induced significant variations in BFA's sesame sector.

According to FAO statistics, total export quantity increased from 20,600 tons in 2007 to 160,000 tons in 2016 (average growth of $22.75 \%$ per annual). In terms of value, sesame seed exports value maintained an average growth of $18.5 \%$ per year over the decade (2007-2016) and export earnings reached 170 million USD (103 billion FCFA in local currency). The buyers of BFA's sesame seed are quite concentrated in Asia such as Japan, Singapore, China and South Korea. With nearly 10\% in world total export of sesame and with an unequaled performance in the production, BFA ranked eighth and fifth as world and Africa's largest exporter of sesame seed in 2016 respectively (FAO database).

Table 1 shows sesame exports quantities, values, and share during the period 2012-2016. Sesame exports in 2012-2016 accounted for about $21 \%$ of agricultural exports value and about $6 \%$ of total exports value of the country, on average. In addition, the logCEP for the sesame sector is greater than one, which highlights the competitiveness of the country in exporting sesame.

Table 1. Sesame export quantities and values in BFA (2012-2016)

\begin{tabular}{|l|l|l|l|l|l|l|}
\hline Years & $\begin{array}{c}\text { Quantity } \\
\text { (ton) }\end{array}$ & $\begin{array}{c}\text { Value } \\
(1000 \text { USD) }\end{array}$ & $\begin{array}{c}\text { Unit value } \\
(\$ / \text { Ton) }\end{array}$ & $\begin{array}{c}\text { Share in agricultural } \\
\text { exports value }(\%)\end{array}$ & $\begin{array}{c}\text { Share in total } \\
\text { exports value } \\
(\%)\end{array}$ & $\begin{array}{c}\text { Export } \\
\text { performance } \\
\text { logCEP }\end{array}$ \\
\hline 2012 & 98,754 & 89,469 & 906 & 20.64 & 4.00 & 4.80 \\
\hline 2013 & 113,093 & 163,803 & 1,448 & 27.73 & 7.12 & 4.97 \\
\hline 2014 & 94,889 & 132,379 & 1,395 & 19.00 & 5.10 & 4.56 \\
\hline 2015 & 171,461 & 169,857 & 991 & 22.34 & 12.13 & 5.28 \\
\hline 2016 & 159,837 & 113,363 & 709 & 16.35 & 4.72 & 4.87 \\
\hline Average & 127,607 & 133,774 & 1,048 & 21.21 & 6.00 & 4.90 \\
\hline
\end{tabular}

Note: CEP: Comparative Export Performance $=\frac{\overline{X_{i B} / X_{B}}}{X_{i A} / X_{A}}$, where $X_{\mathrm{iA}}$ : value of world exports of sesame seed, $\mathrm{X}_{\mathrm{iB}}$ :

value of sesame seed exports from $\mathrm{BF}, \mathrm{X}_{\mathrm{B}}$ : total value of agricultural exports from $\mathrm{BFA}, \mathrm{X}_{\mathrm{A}}$ : total value of world agricultural exports. When $\log C E P>1$ the country has competiveness in the commodity being exported (Balassa, 1965).

In BFA, cotton industry is the principal engine of agricultural exports and a source of economic growth. This sector involves millions of farmers and contributes to $60 \%$ of the total agricultural exports value (FAOSTAT). However, the cotton sector is facing many serious difficulties caused by the downward pressure of world prices and internal problems, which partly led farmers to switch to other cash crops production such as the sesame. This situation has been threatening the country's economy, which depends on agricultural exports. For this reason, the government of BFA through its policies is promoting the diversification of agricultural exports in order to reduce the economy's dependency on cotton sector. Considering the tremendous growth mentioned above in the sesame sector, it turns out that the production and the exports of sesame seed are becoming a source of agricultural exports diversification, an emerging economic sector and another source of income for many farmers. Despite this study's attempt in determining the factors and their effects on seed sesame exports in BFA, there has been no econometrical study carried out on these exports in BFA. This present study turns out to be important in providing information on the factors affecting sesame seed exports in BFA, and to incite conducive actions that would aim to increase export earnings.

This study is conducted to principally investigate the key determinants affecting the sesame seed exports in BFA, to scrutinize their effects, and to analyze the causality between them through the application of the cointegration approach. Specific objectives of the study include the followings:

1. To identify key external and internal factor-drivers of sesame exports in BFA for the period 1970-2016,

2. To quantify the effects and analyze the magnitude of these factors on export performance, and

3. To inform relevant policy prescriptions and agricultural trade recommendations based on the findings.

The rest of the paper is organized as follow: Section 2 briefly presents agricultural and sesame sector in Burkina Faso, Section 3 reviews concisely the literature on the factors affecting agricultural exports in SSA, Section 4 describes econometric methodology used in this study and data descriptions, and Section 5 presents the empirical findings and discussion thereof. The final section presents conclusion remarks and recommendations.

\section{Overview of Agricultural and Sesame Sector in Burkina Faso}

Just like other SSA countries, trade liberalization policies were instituted in 1980s in BFA. The persistent decline in economic growth recorded in post mid-1960s led to the implementation of trade policy reforms to salvage the economy from collapse. Specifically, BFA implemented the Structural Adjustment Program (SAP) in 1983, which aimed to reposition the economy on the path of desired economic growth. The trade reform in 1983 and its fortification in 2000 by the Strategic Framework to Combat Poverty (SFCP), and the adoption of the Accelerated Growth and Sustainable Development Strategy (AGSDS) later in 2011 resulted principally in reducing poverty, sustaining the economic growth and diversifying the agricultural sector. Moreover, the 
principal vision of the current economic program in BFA is still aiming to promote export-led growth through agriculture and to enhance the country's international competitiveness.

Yet, agriculture remains an important sector of BFA's economy and contributes between $35 \%$ and $40 \%$ of the GDP. The sector engages $80 \%$ of the population and is the backbone of economic growth, poverty reduction and sustainable development. Agricultural exports are cotton, livestock products, groundnuts, sesame seed, green beans, shea butter, and fruits among others. In 2016, total exports value of BFA was estimated at 2.4 billiondollar USD (20\% of GDP), with $37.5 \%$ attributed to total agricultural exports (World Bank Indicator data). Cotton industry, the first and the biggest industry, alone contributes to $60 \%$ to agricultural export earnings. However, the cotton sector is facing many serious difficulties caused by the downward pressure of world prices and internal problems, which partly led farmers to switch to other cash crops production.

After cotton, sesame is considered as the second major cash crop for export in BFA, and the country is one of the world's largest producer and exporter. Sesame in BFA is grown entirely under rainfed conditions with little or no use of machinery or modern inputs under the traditional farming system. The seed is cultivated throughout the country, but the major cultivation fields are in western, central and eastern regions. The total production of sesame seed stepped up from 18,802 metric tons in 2007 to 230,000 tons in 2016, corresponding an average growth of $28.45 \%$ per year (FAOSTAT). This is an outstanding performance relative to Africa's larger producers given that Nigeria, Ethiopia and Tanzania recorded an average growth of $14.63 \%, 6 \%$ and $19.70 \%$ per year respectively during the same period. In 2016, BFA was the second in West Africa, the fifth in Africa and the eighth largest producer in the world, with production representing respectively $28 \%, 7 \%$ and $4 \%$ (FAOSTAT). Nevertheless, BFA recorded a low yield in sesame production compared to other producing countries that was on average $603 \mathrm{~kg} / \mathrm{ha}$.

Three main groups of actors lead the sesame sector in BFA: producers, processors and traders/exporters. These actors, called direct actors, are supported by other sectors and actors such as the credit institutions (banks and microfinance structures), the State, non-governmental organizations (NGOs), associations, projects, programs and financial partners (TFP). All these sectors and partners provide financial assistance, training and technical services to the sector's direct actors. Analysis on exports data show that Singapore, China, and Japan are the top market destinations of BFA's sesame seed. Sesame sector in BFA possesses promising aspects including good prospects; land suitability for sesame production; abundant labor; a growing world demand; and amount of sesame seed research and development.

Table 2. Sesame seed production trend in BFA from 2007-2016

\begin{tabular}{|c|l|l|l|}
\hline Crop year & Area (hectare) & Production (ton) & Yield (ton/hectare) \\
\hline $\mathbf{2 0 0 7}$ & 55,058 & 18,802 & 0.3415 \\
\hline $\mathbf{2 0 0 8}$ & 91,997 & 51,924 & 0.5644 \\
\hline $\mathbf{2 0 0 9}$ & 93,384 & 56,252 & 0.6024 \\
\hline $\mathbf{2 0 1 0}$ & 125,471 & 90,649 & 0.7225 \\
\hline $\mathbf{2 0 1 1}$ & 120,750 & 84,759 & 0.7019 \\
\hline $\mathbf{2 0 1 2}$ & 165,575 & 100,488 & 0.6069 \\
\hline $\mathbf{2 0 1 3}$ & 203,449 & 137,347 & 0.6751 \\
\hline $\mathbf{2 0 1 4}$ & 506,095 & 321,837 & 0.6359 \\
\hline $\mathbf{2 0 1 5}$ & 400,000 & 235,000 & 0.5875 \\
\hline $\mathbf{2 0 1 6}$ & 390,000 & 230,000 & 0.5897 \\
\hline Average & 215,178 & 132,706 & 0.6028 \\
\hline AGR\% & 21.62 & 28.45 & - \\
\hline
\end{tabular}

Note: AGR: average growth rate per annual. Source: FAOSTAT, 2018

\section{Review on the Factors Affecting Agricultural Exports in Sub-Saharan Africa}

Determinants of agricultural exports in Sub-Saharan Africa (SSA) countries are still a controversial issue in economics, and studies on the determinants of agricultural exports in developing countries produced mixed results. In general, agricultural exports are affected by multiplicity of factors in low-income countries especially in SSA countries. Allaro (2011) and Fugazza (2004) classified determinants of agricultural exports into external and internal, where external factors are related to market access conditions and other factors affecting import demand. Apart from trade barriers and competition factors foreign market access is also determined by transportation costs, which include geography and physical infrastructures. On the other hand, internal or domestic factors refer to the supply side conditions or factors affecting supply capacity such as domestic policies.

Several studies have been conducted to determine drivers of exports for various agricultural commodities in SSA and have yielded quite interesting findings in economics, business and trade literature. As a key supply side determinant, higher level of production has been found as an important factor for stimulating exports in many studies on export and trade (Bertil, 1968). In an open economy, increased production offers an opportunity for export development through surpluses, which consequently earn foreign exchange, revenue and taxes for the 
exporting country. The rich and cultivable land availability (factor endowment) enables Burkina Faso (BFA) to specialize in the exportation of tropical products (e.g. sesame seed) in which it has comparative advantage in the production. BFA having adopted a more liberal trading environment (open economy), increased production of sesame seed is a priori expected to yield beneficial implications for exports supply (Ngeno, 1966; Boansi, 2014). In the same vein, Boansi et al. (2014) conducted a study on Chad cotton exports by using the Vector Error Correction Model (VECM). The authors used external and supply side factors for a period of 31 years and discovered that, world export volume (proxy of world demand) of the commodity under study and the export competiveness (measured by comparative export performance index) of the product significantly determine cotton lint exports from Chad and Mali. Anwar et al. (2010) using the VECM on cotton lint exports in Pakistan including similar variables as Boansi et al. (2014), revealed that the export of cotton lint is positively driven by increasing world demand for cotton and export competitiveness of the country. Similarly, Kumar et al. (2007) in a study using the same variables as Anwar et al. (2010) concluded that an increase in the volume of world demand of commodities studied leads to an increase in demand for exports from India.

As stated by Dercon (1993), prices generally serve as the basis with which relevant economic policies may affect agricultural variables such as production, exports supply and income. In investigating the determinants of agricultural export growth in Uganda for the period 1987-2006 using the co-integration analysis, Agasha (2009) found that foreign export prices are important determinants of export performance. Edward et al. (2004) studied on the determinants of agricultural exports using the gravity model in South Africa. The authors found a significant effect of foreign export prices on export supply in South Africa. In addition, Allaro (2011) conducted a study on oilseed exports performance in Ethiopia using the VECM and the author found a significant effect of foreign export prices on oilseed. Ndulu et al. (1990) revealed that foreign prices of primary commodities significantly affect the export performance of countries involved in their production.

Moreover, a good producer price matching with foreign export price has a reinforcing effect on agricultural exports performance. Tijani et al. (1999) conducted a study on export supply in Nigeria using the co-integration approach. The empirical finding revealed that producer price has a long-run equilibrium relationship with the cocoa exports in Nigeria, and high producer price leads to accumulation of ample revenue to producers. The author concluded that high price induces producers to increase production of the given product and thus assures the supply and availability of products to export.

Likewise, various studies have also shown that domestic exchange rate depreciation (foreign exchange rate appreciation) makes export products cheaper in the international market resulting in their increased demand. Fang et al. (2006) analyzed the impact of exchange rate depreciation on exports for eight Asian economies and they found that depreciation contributes to exports performance for most countries. In addition, the study of Edward et al. (2004) on the determinants of agricultural exports using the gravity model in South Africa found a significant association between nominal exchange rate and agricultural exports. The study conducted by Allaro (2011) using the VECM in Ethiopia found a positive effect of nominal exchange rate on oilseed exports in the short and long-run. On the contrary, Amoro et al. (2012) in a study on the determinants of agricultural exports in Cote d'Ivoire using the Ordinary Least Square, found a significant and negative effect of nominal exchange rate on cocoa and rubber exports in Cote d'Ivoire. Thus, the devaluation of the nominal exchange rate of a country produces the same effects as the depreciation and enables an increase of its export products. For this reason, WAEMU ${ }^{1}$ in 1994 devaluated the Union's currency, which aimed to stimulate the exports and competitiveness of the member states.

So far, in the literature, various variables have been identified as factors affecting agricultural exports in developing countries. In as much as some of the findings conforming with economics and trade theories, others either are mixed signals or tend to disprove existing theories. However, in either case, knowing the factors that affect agricultural exports is key to drafting and implementing appropriate policy measures to further stimulate exports and boost social and economic development in SSA and particularly in BFA.

\section{Research Methodology}

\subsection{Model Specification}

In this section, we shall recap some essential aspects of the effective use of analytical tools employed in this study. To begin, the export supply models for the various crops are modelled from Goldstein et al. (1978), which was adopted and used in numerous studies such as Islam et al. (1989); Lukonga (1994); Anagaw et al. (2001); Alloro (2001) and Kingu (2014). To identify and analyze the factors affecting sesame seed exports in BFA, the following function is considered:

Xvalue $=f($ Exchrate, Prod, Pdprice, Wexprice, Wexpol)

where Xvalue is exports value or export earnings of sesame seed, Exchrate is the nominal exchange rate

\footnotetext{
${ }^{1}$ West African Economic and Monetary Union (Benin, Bissau Guinea, Burkina Faso, Ivory Coast, Mali, Niger, Senegal and Togo are member States)
} 
(between USD and local currency, FCFA), Prod is the production of sesame seed, Pdprice is producer price or farm gate price of sesame seed, Wexprice is world export price or international price of sesame seed and Wexpvol is world export volume as a proxy for world demand of sesame seed.

In this study, the co-integration approach is applied to study the factors that affect sesame seed exports in BFA. This technique, however, is conditional on the stationarity of the times series variables employed. Again, this technique requires the variables to be integrated (stationary) of the same order; and second, a stationary linear combination must exist (C. J. Granger, 1986; Malik, 2010). These requirements must be satisfied because most economic time series contain unit roots dominated by stochastic trends; and any regression on these series may produce spurious, meaningless and irrelevant results (C. W. Granger \& Newbold, 1974). A stochastic trend is determined by testing the presence of unit roots in the time series data (Elliott, Rothenberg, and James, 1996). The Augmented Dickey Fuller (ADF) test (D. A. Dickey and Fuller, 1981) is used to test for detecting unit roots. The equation for performing the $\mathrm{ADF}$ is expressed as follow:

$$
\Delta Z_{t}=\alpha_{1}+\alpha_{2} t+\alpha_{3} Z_{t-1}+\sum_{i=1}^{p} \beta_{i} \Delta Z_{t-i}+\varepsilon_{t}
$$

where ADF regression tests for existence of unit root of $Z_{t}$, the logarithm values of all model variables at time t. The null (and alternative) hypothesis that tests the presence of unit root in the variable $Z_{t}$ is $\mathrm{H}_{0}: \alpha_{3}=0$ against $\mathrm{H}_{1}: \alpha_{3} \neq 0$.

The nature of stationarity indicates the existence of co-integration and causality, based on the Vector Autoregression (VAR) and the Vector Error Correction Model (VECM) representations. Cointegration test is meant to reveal the presence of long-run equilibrium relationship between the variables. However, a lack of cointegration implies that such variables have no long-run equilibrium relationship and in principle, might wander arbitrarily far away from each other (D. Dickey, Jansen, and Thornton, 1991). The hypothesis that tests this is the null of non-cointegration against an alternative that cointegration exits. This study uses the Johansen (1988) maximum likelihood ratio test and considers two test statistics (Johansen \& Juselius, 1990), that are, the trace statistics and the maximum eigenvalue statistics. They are expressed as follow:

$$
\begin{aligned}
& \lambda_{\text {trace }}=-T \sum_{i=r+1}^{n} \log \left(1-\hat{\lambda}_{i}\right) \\
& \lambda_{\max }=-T \log \left(1-\hat{\lambda}_{r+1}\right)
\end{aligned}
$$

where $\hat{\lambda}_{r+1}, \ldots \hat{\lambda}_{n}$ are (n-r) smallest estimated eigenvalue. The null hypothesis of $\mathrm{r}$ cointegrating vectors is tested here against the alternative hypothesis of $r+1$ cointegrating vectors. The cointegration would determine the types of model, either VAR or VECM that the study may use to analyze the factors affecting sesame seed exports in BFA. First, if the variables employed in this study are stationary and not cointegrated, the following VAR model must be used:

$$
\begin{aligned}
& \text { Xvalue }_{t}=\beta_{0}+\sum_{i=1}^{p} \beta_{1 i} \text { Xvalue }_{t-i}+\sum_{j=1}^{p} \beta_{2 j} \text { Exchrae }_{t-j}+\sum_{k=1}^{p} \beta_{3 k} \text { Prod }_{t-k}+\sum_{r=1}^{p} \beta_{4 r} \text { Pdprice }_{t-r}+ \\
& \quad \sum_{n=1}^{p} \beta_{5 n} \text { Wexprice }_{t-n}+\sum_{m=1}^{p} \beta_{6 m} \text { Wexpvol }_{t-m}+\mu_{1 t}(5) \\
& \text { Exchrate }_{t}=\alpha_{0}+\sum_{i=1}^{p} \alpha_{1 i} \text { Exchrate }_{t-i}+\sum_{j=1}^{p} \alpha_{2 j} \text { Xvalue }_{t-j}+\sum_{k=1}^{p} \alpha_{3 k} \text { Prod }_{t-k}+\sum_{r=1}^{p} \alpha_{4 r} \text { Pdprice }_{t-r}+ \\
& \sum_{n=1}^{p} \alpha_{5 n} \text { Wexprice }_{t-n}+\sum_{m=1}^{p} \alpha_{6 m} \text { Wexpvol }_{t-m}+\mu_{2 t} \quad(6) \\
& \text { Prod }_{t}=\gamma_{0}+\sum_{i=1}^{p} \gamma_{1 i} \text { Prod }_{t-i}+\sum_{j=1}^{p} \gamma_{2 j} \text { Exchrate }_{t-j}+\sum_{k=1}^{p} \gamma_{3 k} \text { Prod }_{t-k}+\sum_{r=1}^{p} \gamma_{4 r} \text { Pdprice }_{t-r}+ \\
& \quad \sum_{n=1}^{p} \gamma_{5 n} \text { Wexprice }_{t-n}+\sum_{m=1}^{p} \gamma_{6 m} \text { Wexpvol }_{t-m}+\mu_{3 t}(7) \\
& \text { Pdprice }_{t}=\eta_{0}+\sum_{i=1}^{p} \eta_{1 i} \text { Pdprice }_{t-i}+\sum_{j=1}^{p} \eta_{2 j} \text { Exchrae }_{t-j}+\sum_{k=1}^{p} \eta_{3 k} \text { Prod }_{t-k}+\sum_{r=1}^{p} \eta_{4 r} \text { Xvalue }_{t-r}+ \\
& \quad \sum_{n=1}^{p} \eta_{5 n} \text { Wexprice }_{t-n}+\sum_{m=1}^{p} \eta_{6 m} \text { Wexpvol }_{t-m}+\mu_{4 t} \quad(8) \\
& \text { Wexprice }_{t}=\delta_{0}+\sum_{i=1}^{p} \delta_{1 i} \text { Wexprice }_{t-i}+\sum_{j=1}^{p} \delta_{2 j} \text { Exchrae }_{t-j}+\sum_{k=1}^{p} \delta_{3 k} \text { Prod }_{t-k}+\sum_{r=1}^{p} \delta_{4 r} \text { Pdprice }_{t-r} \\
& \quad+\sum_{n=1}^{p} \delta_{5 n} \text { Xvalue }_{t-n}+\sum_{m=1}^{p} \delta_{6 m} \text { Wexpvol }_{t-m}+\mu_{5 t} \quad(9) \\
& \text { Wexpvol }_{t}=\lambda_{0}+\sum_{i=1}^{p} \lambda_{1 i} \text { Wexpvol }_{t-i}+\sum_{j=1}^{p} \lambda_{2 j} \text { Exchrae }_{t-j}+\sum_{k=1}^{p} \lambda_{3 k} \text { Prod }_{t-k}+\sum_{r=1}^{p} \lambda_{4 r} \text { Pdprice }_{t-r}+ \\
& \sum_{n=1}^{p} \lambda_{5 n} \text { Wexprice }_{t-n}+\sum_{m=1}^{p} \lambda_{6 m} \text { Xvalue }_{t-m}+\mu_{6 t} \quad(10)
\end{aligned}
$$

here $\beta, \alpha, \gamma, \eta, \delta$ and $\lambda$ are parameters.

Second, if the variables used in this study are cointegrated, then the VECM shown below would be applied:

$\Delta$ Xvalue $_{t}=\beta_{1}+\sum_{l=1}^{p} \alpha_{11, l} \Delta X$ value $_{t-l}+\sum_{l=1}^{p} \gamma_{12, l} \Delta$ Exchrate $_{t-l}+\sum_{l=1}^{p} \eta_{13, l} \Delta$ Prod $_{t-l}+\sum_{l=1}^{p} \delta_{14, l} \Delta$ Pdprice $_{t-l}$

$$
\sum_{l=1}^{p} \lambda_{15, l} \Delta \text { Wexprice }_{t-l}+\sum_{l=1}^{p} \phi_{16} \Delta \text { Wexpvol }_{t-l}+\rho_{1} \text { ECT }_{t-1}+\pi_{t}
$$

$\Delta$ Exchrate $_{t}=\beta_{2}+\sum_{l=1}^{p} \alpha_{21, l} \Delta$ Exchrate $_{t-l}+\sum_{l=1}^{p} \gamma_{22, l} \Delta$ Xvalue $_{t-l}+\sum_{l=1}^{p} \eta_{23, l} \Delta$ Prod $_{t-l}+$ $\sum_{l=1}^{p} \delta_{24, l} \Delta$ Pdprice $_{t-l}+\sum_{l=1}^{p} \lambda_{25, l} \Delta$ Wexprice $_{t-l}+\sum_{l=1}^{p} \phi_{26} \Delta$ Wexpvol $_{t-l}+\rho_{2}$ ECT $_{t-1}+\pi_{t}$ (12)

$\Delta \operatorname{Prod}_{t}=\beta_{3}+\sum_{l=1}^{p} \alpha_{31} \Delta \operatorname{Prod}_{t-l}+\sum_{l=1}^{p} \gamma_{32, l} \Delta$ Exchrate $_{t-l}+\sum_{l=1}^{p} \eta_{33, l} \Delta X$ value $_{t-l}+\sum_{l=1}^{p} \delta_{34, l} \Delta$ Pdprice $_{t-l}$ $+\quad \sum_{l=1}^{p} \lambda_{35, l} \Delta$ Wexprice $_{t-l}+\sum_{l=1}^{p} \phi_{36} \Delta$ Wexpvol $_{t-l}+\rho_{3} E C T_{t-1}+\pi_{t}$

$\Delta$ Pdprice $_{t}=\beta_{4}+\sum_{l=1}^{p} \alpha_{41} \Delta$ Pdprice $_{t-l}+\sum_{l=1}^{p} \gamma_{42, l} \Delta$ Exchrate $_{t-l}+\sum_{l=1}^{p} \eta_{43, l} \Delta$ Prod $_{t-l}+$ 


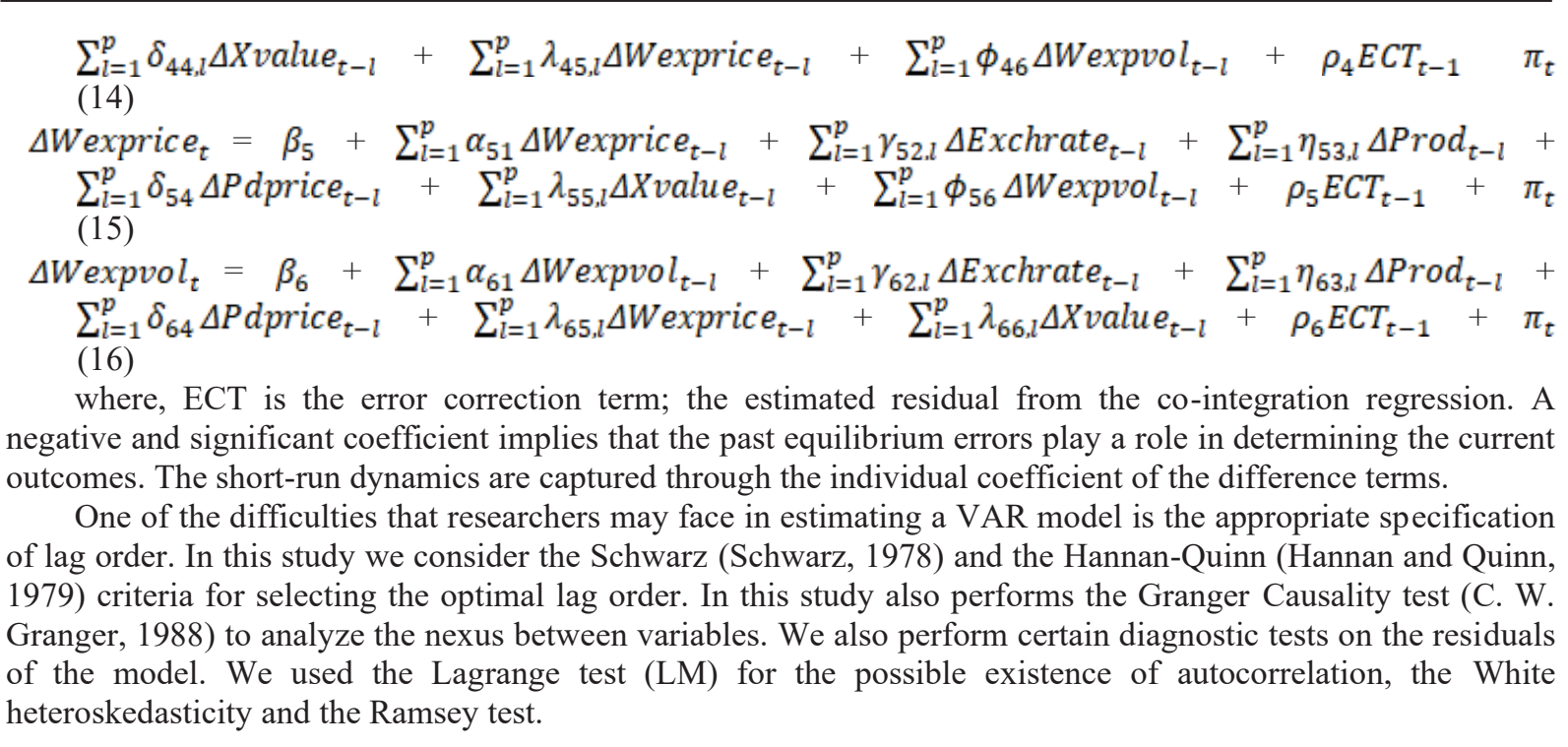

\subsection{Data Source and Description}

The data employed for this research are annual and cover the period 1970 to 2016 obtained from FAOSTAT, World Bank Indicators and INSD (Institute of National Statistics and Demography, INSD BFA) database. Both producer price and world export price were measured in USD dollar per ton, while exports value was measured in USD dollar. In addition, production and world demand of sesame seed were measured in ton. In the analysis, all data were expressed logarithmically in order to include the proliferative effect of time series. Table 3 provides the summary statistics for all variables employed in this study.

Table 3. Summary statistics

\begin{tabular}{|l|l|l|l|l|l|l|}
\hline & \multicolumn{1}{|c|}{ Xearnings } & \multicolumn{1}{c|}{ Exchrate } & \multicolumn{1}{c|}{ Prod } & \multicolumn{1}{c|}{ Pdprice } & \multicolumn{1}{c|}{ Wexprice } & \multicolumn{1}{c|}{ Wexpvol } \\
\hline Mean & $20,270,021$ & 416,09 & 35895,32 & 538,04 & 825,94 & 663393,85 \\
\hline Max & $169,857,000$ & 733,03 & 321837,00 & 2451,15 & 2059,36 & 1895582,00 \\
\hline Min & 31,8000 & 211,27 & 1676,00 & 108,53 & 232,60 & 183008,00 \\
\hline Std. Dev & $42,464,717$ & 152,65 & 67013,62 & 588,83 & 361,71 & 473696,02 \\
\hline Skewness & 2,50 & 0,24 & 2,87 & 2,06 & 1,60 & 1,10 \\
\hline Kurtosis & 7,85 & 1,87 & 10,83 & 6,37 & 4,85 & 3,21 \\
\hline
\end{tabular}

Note: FCFA: currency of Burkina Faso

\section{Empirical Results and Discussion}

\subsection{Stationarity}

The empirical analysis begins with checking stationarity of the time series variables as a prime condition for cointegration and using either VAR or VECM. The ADF unit root test has been applied to examine the stationarity of the time series data. The estimated results of unit root test are reported in Table 4. 
Table 4. Unit root test results

\begin{tabular}{|c|c|c|c|}
\hline \multirow[t]{2}{*}{ Variables } & \multicolumn{2}{|c|}{ Level data } & \multirow[t]{2}{*}{ Conclusion } \\
\hline & Constant & Constant with trend & \\
\hline $\log$ Xvalue & 1.12 & -1.47 & Non-stationary \\
\hline logExchrate & 0.23 & -2.20 & Non-stationary \\
\hline logProd & 1.12 & -0.54 & Non-stationary \\
\hline logPdprice & -1.28 & -2.07 & Non-stationary \\
\hline logWexprice & -2.49 & -2.90 & Non-stationary \\
\hline logWexpvol & -1.03 & -3.55 & Non-stationary \\
\hline \multicolumn{4}{|c|}{ First difference } \\
\hline logXvalue & -9.95 & $-10.08 * * *$ & Stationary \\
\hline logExchrate & -5.96 & $-5.90 * * *$ & Stationary \\
\hline logProd & -7.29 & $-7.73 * * *$ & Stationary \\
\hline logPdprice & -6.37 & $-6.30 * * *$ & Stationary \\
\hline logWexprice & -6.18 & $-6.24 * * *$ & Stationary \\
\hline logWexpvol & -6.43 & $-5.78 * * *$ & Stationary \\
\hline
\end{tabular}

Note: Xvalue: exports value; Exchrate: nominal exchange rate; Prod: production; Pdprice: producer price;

Wexprice: world export price; Wexpvol: world demand; log: natural logarithm; and *** indicates statically significant at $1 \%$.

The results indicate that no time series variables appear to be stationary in variable level, since computed test statistics could not reject the null hypothesis of non-stationarity. This signifies that the variables are nonstationary in their level data. It suggests that the stationarity must be checked at a higher order of differencing. In this present study, it is found that when the first differences of the variables are considered, the null hypothesis of unit root is rejected at $1 \%$ significance level. Hence, the differences become stationary and as a result the related variables are integrated of order one, I (1). The optimal lag selection is considered by using the Schwarz (SC) and the Hannan-Quinn (HQ). The result the VAR lag order selection is reported in Table 5.

Table 5. VAR lag order selection

\begin{tabular}{|c|l|l|l|l|l|}
\hline Lag order & \multicolumn{1}{|c|}{ LR } & \multicolumn{1}{|c|}{ FPE } & \multicolumn{1}{c|}{ AIC } & \multicolumn{1}{c|}{ HQ } \\
\hline 0 & NA & $1.33 \mathrm{E}-05$ & 5.8 & 6.04 & 5.89 \\
\hline 1 & $293.82 *$ & $2.48 \mathrm{e}-08^{*}$ & $-0.5^{*}$ & $1.2^{*}$ & $0.12^{*}$ \\
\hline 2 & 48.96 & $2.88 \mathrm{E}-08$ & -0.44 & 2.71 & 0.72 \\
\hline 3 & 40.86 & $3.72 \mathrm{E}-08$ & -0.43 & 4.17 & 1.27 \\
\hline
\end{tabular}

Note: LR: sequential modified test statistic; FPE: final prediction error; AIC: Akaike information criterion; SC:

Schwarz information criterion; HQ: Hannan-Quinn information criterion; and * indicates optimal lag criteria.

\subsection{Cointegration}

Following that, the series are integrated of order one, the cointegration relationship between them are established by using Johansen's maximum likelihood (ML) test. The results of cointegration test $\left(\lambda_{\text {trace }}\right.$ and $\left.\lambda_{\max }\right)$ indicate that the time series variables (exports value, exchange rate, production, producer price, world export price and world demand) are cointegrated (see Table 6) and hence, long-run equilibrium relationship may exist among them.

Table 6. Cointegration test results

\begin{tabular}{|l|l|l|l|l|}
\hline \multicolumn{1}{|c|}{ Null hypothesis } & \multicolumn{1}{c|}{ Trace statistic } & \multicolumn{1}{c|}{$5 \%$ critical value } & \multicolumn{1}{c|}{ Max Eigenvalue } & \multicolumn{1}{c|}{$5 \%$ critical value } \\
\hline $\mathrm{H}_{0}: \mathrm{r}=0$ & 92.84 & 83.93 & 39.52 & 36.63 \\
\hline $\mathrm{H}_{0}: \mathrm{r} \leq 1$ & $53.32^{* *}$ & 60.06 & $22.83^{* *}$ & 30.43 \\
\hline $\mathrm{H}_{0}: \mathrm{r} \leq 2$ & 30.49 & 40.17 & 12.07 & 24.15 \\
\hline $\mathrm{H}_{0}: \mathrm{r} \leq 3$ & 18.41 & 24.27 & 10.74 & 17.79 \\
\hline $\mathrm{H}_{0}: \mathrm{r} \leq 4$ & 7.66 & 12.32 & 7.39 & 11.22 \\
\hline $\mathrm{H}_{0}: \mathrm{r} \leq 5$ & 0.275 & 4.12 & 0.27 & 4.12 \\
\hline
\end{tabular}

Note: $r$ denotes the number of cointegrating vectors; and ** indicates statistically significant at $5 \%$.

The existence of cointegration leads us toward the use of the VECM (expressed by equations (11) - (16)).

The VECM is applied to analyze the factors affecting sesame seed exports in BFA and to know the causality between the factors. This model gives us the short-run dynamics and long-run estimates. The short-run results indicate that the nominal exchange rate, producer price, international price, and world demand of sesame seed are factors affecting sesame seed exports in BFA (with export value-Xvalue being our target dependent variable).

The estimated results of the VECM are reported in Table 7. D1-D4 are dummy variables included to control for short-run structural break. The study used the Zivot-Andrews unit roots test with structural break to define 
the dummy variables. These dummy variables take one at the break point and zero otherwise. The break points are represented by D1-D4, and concern the nominal exchange rate, exports value, production and world export price, respectively.

A $1 \%$ depreciation of the nominal exchange rate (or $1 \%$ increase in the value of the USD) will increase export earnings or value by $2.30 \%$ in the short-run. This is in line with Allaro (2011) results, which found positive and significant short-run effect of nominal exchange rate on oilseed exports in Ethiopia. Similarly, it is expected that a $1 \%$ increase in farm gate price or producer will affect exports performance by $0.58 \%$ in the shortrun. This finding supports the result of Okoruwa et al. (2003) who reported that an increase in producer's price of rubber is associated with an increase in exports of rubber in Nigeria. A $1 \%$ increase in world market price of sesame increases exports value for BFA by $1.30 \%$. Boansi et al. (2014) also found that, in short-run; world price causes cotton exports performance in Mali.

Table 7. Estimation results of the VECM

\begin{tabular}{|c|c|c|c|c|c|c|}
\hline \multicolumn{7}{|c|}{ Short-run dynamics (one lag included) } \\
\hline $\begin{array}{l}\text { Dependent } \\
\text { variables }\end{array}$ & $\begin{array}{l}\Delta \log \text { Xvalu } \\
\mathrm{e}\end{array}$ & $\begin{array}{l}\Delta \log \text { Exchrat } \\
\mathrm{e}\end{array}$ & $\Delta \log$ Prod & $\Delta \log P d p r i c e$ & $\begin{array}{l}\Delta \log \text { Wexpric } \\
\mathrm{e}\end{array}$ & $\begin{array}{l}\Delta \operatorname{logwexpvo} \\
1\end{array}$ \\
\hline$\Delta \log X$ value & $\begin{array}{l}-0.16 \\
(-1.04)\end{array}$ & $\begin{array}{l}-0.08 * * * \\
(-2.88)\end{array}$ & $\begin{array}{l}-0.03 \\
(-0.20)\end{array}$ & $\begin{array}{l}0.06 \\
-0.65\end{array}$ & $\begin{array}{l}0.06 \\
-1.11 \\
\end{array}$ & $\begin{array}{l}-0.06 \\
(-1.62)\end{array}$ \\
\hline$\Delta \log$ Exchrate & $\begin{array}{l}2.30 * * * \\
(4.00)\end{array}$ & $\begin{array}{l}0.08 \\
(0.76)\end{array}$ & $\begin{array}{l}0.48 \\
(0.86)\end{array}$ & $\begin{array}{l}-0.23 \\
(-0.67)\end{array}$ & $\begin{array}{l}-0.03 \\
(-0.15)\end{array}$ & $\begin{array}{l}-0.18 \\
(1.24)\end{array}$ \\
\hline$\Delta \log$ Prod & $\begin{array}{l}0.01 \\
(0.09)\end{array}$ & $\begin{array}{l}0.11 * * * \\
(3.87)\end{array}$ & $\begin{array}{l}-0.24 \\
(-1.62)\end{array}$ & $\begin{array}{l}-0.17 * \\
(-1.79)\end{array}$ & $\begin{array}{l}-0.18 * * * \\
(-3.17)\end{array}$ & $\begin{array}{l}0.06 \\
(1.56)\end{array}$ \\
\hline$\Delta \log$ Pdprice & $\begin{array}{l}0.58 * \\
(1.87)\end{array}$ & $\begin{array}{l}-0.03 \\
(-0.57)\end{array}$ & $\begin{array}{l}0.12 \\
(0.41)\end{array}$ & $\begin{array}{l}0.01 \\
(0.09)\end{array}$ & $\begin{array}{l}0.14 \\
(1.27)\end{array}$ & $\begin{array}{l}0.06 \\
(0.84)\end{array}$ \\
\hline$\Delta \log$ Wexprice & $\begin{array}{l}1.30 * * \\
(2.46)\end{array}$ & $\begin{array}{l}-0.17 * \\
(-1.73)\end{array}$ & $\begin{array}{l}0.00 \\
(-0.01) \\
\end{array}$ & $\begin{array}{l}0.18 \\
(0.58) \\
\end{array}$ & $\begin{array}{l}0.22 \\
(1.14) \\
\end{array}$ & $\begin{array}{l}-0.05 \\
(-0.37)\end{array}$ \\
\hline$\Delta \operatorname{logwexpvol}$ & $\begin{array}{l}2.11 * * * \\
(3.66)\end{array}$ & $\begin{array}{l}-0.08 \\
(-0.75)\end{array}$ & $\begin{array}{l}0.53 \\
(0.94)\end{array}$ & $\begin{array}{l}0.26 \\
(0.73)\end{array}$ & $\begin{array}{l}0.17 \\
(0.83)\end{array}$ & $\begin{array}{l}-0.04 \\
(-0.27)\end{array}$ \\
\hline D1 & $\begin{array}{l}-0.17 \\
(-0.36)\end{array}$ & $\begin{array}{l}0.70 * * * \\
(7.77)\end{array}$ & $\begin{array}{l}-1.50 * * * \\
(-3.18)\end{array}$ & $\begin{array}{l}0.00 \\
(0.02)\end{array}$ & $\begin{array}{l}0.15 \\
(0.87)\end{array}$ & $\begin{array}{l}0.15 \\
(1.27)\end{array}$ \\
\hline D2 & $\begin{array}{l}-0.44 \\
(-0.90)\end{array}$ & $\begin{array}{l}-0.35 * * * \\
(3.86)\end{array}$ & $\begin{array}{l}0.22 \\
(0.46)\end{array}$ & $\begin{array}{l}-0.02 \\
(-0.08)\end{array}$ & $\begin{array}{l}-0.15 \\
(-0.84)\end{array}$ & $\begin{array}{l}0.07 \\
(0.61)\end{array}$ \\
\hline D3 & $\begin{array}{l}0.37 \\
(1.12)\end{array}$ & $\begin{array}{l}-0.07 \\
(-1.20)\end{array}$ & $\begin{array}{l}0.17 \\
(0.53)\end{array}$ & $\begin{array}{l}0.45 * * \\
(2.21)\end{array}$ & $\begin{array}{l}0.22 * * \\
(1.79)\end{array}$ & $\begin{array}{l}-0.08 \\
(-0.95)\end{array}$ \\
\hline D4 & $\begin{array}{l}-0.12 \\
(-0.24)\end{array}$ & $\begin{array}{l}-0.07 \\
(-0.81)\end{array}$ & $\begin{array}{l}-0.22 \\
(-0.45)\end{array}$ & $\begin{array}{l}0.20 \\
(0.65)\end{array}$ & $\begin{array}{l}0.07 \\
(0.40)\end{array}$ & $\begin{array}{l}-0.25 * \\
(-1.91)\end{array}$ \\
\hline ECT & $\begin{array}{l}-0.36 * * \\
(-2.44)\end{array}$ & $\begin{array}{l}0.10 * \\
(3.81) \\
\end{array}$ & $\begin{array}{l}0.35 * * \\
(2.40)\end{array}$ & $\begin{array}{l}-0.03 \\
(-0.38)\end{array}$ & $\begin{array}{l}-0.06 \\
(-1.22)\end{array}$ & $\begin{array}{l}0.09 * * \\
(2.39)\end{array}$ \\
\hline \multicolumn{7}{|c|}{ Long-run equilibrium } \\
\hline \multirow[t]{2}{*}{$\log$ Xvalue } & $\begin{array}{c}\log \text { Exchrat } \\
\mathrm{e}\end{array}$ & $\log$ Prod & $\begin{array}{c}\log \text { Pdpric } \\
\text { e }\end{array}$ & $\begin{array}{c}\log \text { Wexpric } \\
\mathrm{e}\end{array}$ & \multicolumn{2}{|c|}{ logWexpvol } \\
\hline & $\begin{array}{l}1.13 * * * \\
(3.71)\end{array}$ & $\begin{array}{l}1.43 * * * \\
(10.11)\end{array}$ & $\begin{array}{l}0.20 \\
(0.90)\end{array}$ & $\begin{array}{l}-1.14 * * * \\
(-4.06)\end{array}$ & $\begin{array}{l}0.05 \\
(0.25)\end{array}$ & \\
\hline
\end{tabular}

Note: D1-D4 are dummy variables included as exogenous variables in the VECM to control for structural break.

This concerns Xvalue, Exchrate, Prod and Wexprice variables. Numbers in the brackets (...) are t statistics,

$* * *$ indicates statistically significant at $1 \%, * *$ statistically significant at $5 \%$ and $*$ statistically significant at $10 \%$.

According to the principles of trade theory, an inverse association is usually expected between prices and world exports volume or world demand. This is because whenever prices in the international market increase, international consumers are expected to demand less, while exporting countries on the other hand are expected to export more. However, in this study a $1 \%$ increase in world demand of sesame seed will increase exports value by $2.11 \%$. The positive effect of world demand and world market price of sesame seed on BFA's exports performance reflects a good standing of the commodity involved in the international market as pointed out by Kumar et al. (2007).

Furthermore, none of the dummy variable has a significant effect on exports value; however, D1 has a significant effect on exchange rate and production. BFA has devaluated its currency in 1994, which is represented by D1. This has depreciated the currency, stimulated the sesame seed exports and affected significantly sesame production. The effect of D3 on producer price and world export price is negative and significant. D3 is included to control for structural break and concern production variable. It implies that the 
structural change happened in 2008 (financial crisis) had a negative impact on world price of sesame seed. The ECT coefficient (-0.36) is negative and statistically significant. This implies that the past equilibrium errors play a role in determining the current outcomes or suggests an existence of a high speed of convergence to long-run relationship (equilibrium) amongst the variables.

The long-run estimates point out that nominal exchange rate, production and world export price of sesame seed are factors determining sesame seed exports in BFA. Like in the short-run, nominal exchange rate remains a major factor in determining exports for the long-run. In the long-run, a 1\% depreciation of the nominal exchange rate (or $1 \%$ increase in the value of the USD) will increase exports value by $1.13 \%$ for BFA. This result again confirms the finding of Allaro (2011), which, in the long-run, reveals that the nominal exchange rate is a key determinant of oilseed exports in Ethiopia.

The variable production was not a significant factor in determining sesame seed exports in the short-run. However, the production of sesame seed has an elastic long-run effect on export performance. It is projected that a $1 \%$ increase in the production is associated with $1.43 \%$ increase in the exports value of sesame seed for BFA. This finding is in line with Ball et al. (1966) and Bertil (1968) who reported that production is a key supply side determinant of exports, thus increased production stimulates exports expansion and performance.

Unlike the short-run, the world export price of sesame seed has a negative sign and is significant. A $1 \%$ increase in world export price decreases exports value by $1.14 \%$. In fact, exporters are motivated to export more and to expect higher gains when there is a positive response in price increments. However, in equilibrium they are hindered in doing so by the downward pressure of world prices, which makes sesame seed in the international market and other sources cheaper than the one offered by BFA.

To complement this study, we report also the diagnostic tests for serial correlation (LM test), heteroskedasticity (White test) and stability test (Ramsey test). These diagnostic tests aim to test the absence of residuals serial correlation, the robustness and the stability of the coefficients. These are provided in Table 8 .

Table 8. Short-run diagnostic tests

\begin{tabular}{|l|l|l|l|}
\hline Test & \multicolumn{1}{|c|}{ LM } & \multicolumn{1}{|c|}{ White } & Ramsey \\
\hline Value & $1.05^{* *}$ & $15.27 * *$ & $1.78^{* *}$ \\
\hline
\end{tabular}

Note: LM: Serial correlation; Ramsey: Ramsey test; White: White heteroskedasticity test; * indicates that the test statistics is significant at $5 \%$.

\subsection{Causality}

The findings of the variables' stationarity, co-integration between variables employed and significance of the ECT immediately implies that there is causality between the variables in the short and long-run. Therefore, it would be useful and relevant to test for causality in order to note the causal relationship between the variables. Thus, the test results can help to find out key pathways and key factors that affect exports value. The short-run null hypothesis is stated as: there is no short-run causality going from variable $\mathrm{X}$ to variable $\mathrm{Y}$ and the long-run causality null hypothesis is similarly stated as the short-run. The null hypothesis is rejected (accepting a causality) if the chi-square is statistically significant. The short-run causality is tested by using the Granger short-run causality test. However, the long-run causality test is conducted by using Wald test based on the ECT's coefficient. Short-run and long-run causality tests are displayed in Table 9.

The results of causality presented above show unidirectional causality in the short-run going from producer price to exports value. Unidirectional causality is also noted from world export price and world demand to exports value. It simply means that a rise in any of these factors causes a rise in exports value for BFA. The analysis also finds unidirectional causality in the short-run going from production and world export price to exchange rate. This suggests that a rise in production or world export price causes a rise in nominal exchange rate. A short-run unidirectional causality also exists between production and producer price, and between production and world export price. 
Table 9. Results of causality tests

\begin{tabular}{|c|c|c|c|c|c|c|}
\hline \multicolumn{7}{|c|}{ Short-run causality (in first difference) } \\
\hline Dependent variable & logXvalue & logExchrate & logProd & logPdprice & logWexprice & logWexpvol \\
\hline logXvalue & - & $(8.30) * * *$ & $(0.04)$ & $(0.42)$ & $(1.24)$ & $(2.65)$ \\
\hline logExchrate & $(16.06) * * *$ & - & $(0.74)$ & $(0.45)$ & $(0.02)$ & $(1.55)$ \\
\hline $\log$ Prod & $(0.00)$ & $(14.80)^{* * *}$ & - & $(3.22) *$ & $(10.06) * * *$ & $(2.46)$ \\
\hline logPdprice & $(3.52) *$ & $(0.26)$ & $(0.17)$ & - & $(1.63)$ & $(0.70)$ \\
\hline logWexprice & $(6.07) * *$ & $(3.19) *$ & 0.00 & $(0.33)$ & - & $(0.13)$ \\
\hline logWexpvol & $(13.40) * * *$ & $(0.56)$ & $(0.89)$ & $(0.53)$ & $(0.70)$ & - \\
\hline \multicolumn{7}{|c|}{ Long-run causality } \\
\hline Dependent variable & logXvalue & logExchrate & logProd & logPdprice & logWexprice & logWexpvol \\
\hline logXvalue & - & $(14.99) * * *$ & $(8.51)^{* *}$ & $(0.42)$ & $(1.70)$ & $(5.77)^{*}$ \\
\hline logExchrate & $(19.31) * * *$ & - & $(7.41)^{* *}$ & $(0.70)$ & $(1.62)$ & $(6.48) * *$ \\
\hline logProd & $(7.77) * *$ & $(20.23) * * *$ & - & $(3.45)$ & $(10.11) * * *$ & $(6.04) * *$ \\
\hline logPdprice & $(10.51) * * *$ & $(15.40) * * *$ & $(5.80) *$ & - & $(3.47)$ & $(6.11) * *$ \\
\hline logWexprice & $(8.43) * *$ & $(14.60) * * *$ & $(7.04) * *$ & $(0.37)$ & - & $(6.27) * *$ \\
\hline logWexpvol & $(17.27) * * *$ & $(14.64) * * *$ & $(7.41)^{* *}$ & $(0.61)$ & $(1.95)$ & - \\
\hline
\end{tabular}

Note: numbers between the brackets (...) are Chi-square statistics, $* * *$ indicates statistically significant at $1 \%$, ** statistically significant at $5 \%$ and $*$ statistically significant at $10 \%$.

In addition, this study finds bidirectional causality in the short-run between nominal exchange rate and exports value. A point needs to be made here regarding bidirectional causality. If the rise in one variable causes the rise of another, and is also true when the variables are switched, the variables would reinforce each other and be self-reinforcing. This situation, therefore, would be easy to handle by policy maker (Chontanawat, 2019).

In the long-run, this work discovered bidirectional causality from nominal exchange rate to exports value, from production to exports value, and from world demand of sesame seed to exports value for BFA. The same type of causality is verified also between exports value and world demand of sesame seed. A bidirectional causality is also observed between nominal exchange rate and production, and between nominal exchange rate and world demand. The long-run bidirectional causality is again noticed between production and world demand. In the long-run, unidirectional causality is going only from world export price to exports value, from producer price to exports value, and from producer price to production.

\section{Concluding Remarks and Policy Implications}

\subsection{Summary of Findings}

This study has examined the factors affecting sesame seed exports in BFA using the VECM with time series data for the 1970-2016 period. It has also analyzed the causality between these determinants using the Granger causality test. The short-run empirical evidence from our study suggests that nominal exchange rate, producer price, world price and demand significantly determine the sesame seed earnings in BFA. For the long run, nominal exchange rate, production and world price have a significant burnt on sesame seed earnings in BFA. Thus, BFA's exports of sesame seed are determined by both internal factors such as producer price, production, nominal exchange rate and by external factors such as world demand and price, in the short and long-run.

The findings reveal that after the currency's devaluation sesame seed export earnings showed improvement. The error correction term in the model is found to be statistically significant, and this suggests a high speed of convergence to equilibrium. The coefficient estimate of the error correction term in our model is $(-0.3686)$ and this implies that variables adjust to long-run equilibrium at the speed of 36 percent per annum as such confirming the validity of the long-run relationship (equilibrium) amongst the variables. This indicates a high speed of adjustment of variables to equilibrium.

\subsection{Conclusions and Recommendations}

With a continuous increase in world demand of sesame seed, the study is deemed to be vital in the effective design and implementation of policies aimed to increase BFA's export earnings of sesame seed. The study concludes with the following:

First, production is a factor that determines sesame seed exports value and there is bidirectional causality between production and export earnings. It means that production causes export earnings and vice versa. Sesame seed is a cash crop for farmers in BFA; therefore, a higher revenue from sesame exports is an incentive to produce more. The potentiality to expand produced quantities is a factor that will increase sesame seed export earnings, ceteris paribus. Hence, it is important to boost the production, and this could be achieved through increasing significantly yields; by supporting farmers in diverse ways, including provision of adapted financial credits, input distribution (modern technologies, fertilizers, pesticides, and improved seed) as well as improving 
the quality of the sesame being exported.

Second, bidirectional causality between exports value and world demand of sesame seed was found in this study. This implies that when world demand steps up, exports value is expected to increase through the increase of world price. The increase in world demand raises world price, which will significantly affect export earnings, all things being equal. In addition, producer price has significant effect on the export earnings and production. The implication is that an increase in the producer price of sesame seed to match export price will encourage farmers to increase the output. However, a huge gap between export price and farm gate price discourage farmers from fully participating in sesame seed production. Hence, ensuring an appropriate transmission of export prices increments to farmers could contribute to incentivize them, thereby increasing production and exports earnings.

Finally, we also found bidirectional causality between nominal exchange rate and exports value; and between nominal exchange rate and world demand of sesame seeds. As pointed out by trade and economics literature, exchange rate is an important factor that determines the exports of any country. A policy aimed to depreciate local currency could have an impact on exports performance of sesame seed. In other words, the appreciation of the USD would have a positive effect on exports value. The unidirectional causality from producer price to exports value is important to highlight. Farmers' earnings are determined mainly by gate price, therefore, ensuring that an acceptable margin between the producer prices and export price of sesame seed would be beneficial to farmers in boosting their revenues and economic fallouts.

Our study, so far, has scrutinized the factors affecting the sesame seed exports in Burkina Faso. However, the trade between countries, a country's competitiveness and its international market share could be influenced by numerous factors. Thus, it may be prospectively important to study the determinants of trade flows and trade structure of sesame seed between BFA and its major buyers (Japan and China). This will not only complete the present study in terms of recommendations, but also will end up with trade policies aimed to increase the competitiveness and market share of BFA in the international market.

\section{References}

Agasha, N. (2009). Determinants of export growth in Uganda (1987-2006). Makerere University, Kampala, Uganda.(Unpublished master's thesis).

Allaro, H. B. (2011). Export Performance of Oilseeds and its Determinants in Ethiopia. Journal of Cereals and Oilseeds, 2(1), 1-15.

Amoro, G., and Shen, Y. (2012). The Determinants of Agricultural Export: Cocoa and Rubber in Cote d'Ivoire. International Journal of Economics and Finance, 5(1), 228-233.

Anagaw, B. K., and Demissie, W. M. (2001). Determinants of Export Performance in Ethiopia: VAR Model Analysis. Journal of Research in Commerce and Management, 2, 5-94.

Anwar, S., Shaukat, F., and Hussain, Z. (2010). Impact of Trade Liberalization on Export of Cotton from Pakistan: a Time Series Analysis. Sarhad Journal of Agriculture, 26(2), 297-304.

Balassa, B. (1965). Trade Liberalisation and "Revealed" Comparative Advantage. The Manchester School, 33(2), 99-123.

Ball, R. J., Eaton, J., and Steuer, M. (1966). The Relationship between United Kingdom Export Performance in Manufactures and the Internal Pressure of Demand. The Economic Journal, 76(303), 501-518.

Bertil, O. (1968). Model construction in international trade theory. In W.A Eltis, M. FG., Scott \& JN Wolfe (Eds.), Induction, Growth and Trade, (pp.325-341). Oxford: Clarendon Press.

Boansi, D., Lokonon, B. O. K., and Appah, J. (2014). Co-integration Analysis of the Determinants of Cotton Lint Exports from Mali. Asian J. Agricultural Extension. Economics and Sociology, 3(6), 544-561.

Boansi, D., Odilon Kounagbé Lokonon, B., and Appah, J. (2014). Determinants of Agricultural Export Trade: Case of Fresh Pineapple Exports from Ghana. British Journal of Economics, Management and Trade, 2, 1736-1754.

Brüntrup, M., and Zimmermann, R. (2009). Agriculture as the Potential Engine for African Growth and the Role of NEPAD. Paper presented at the CESifo Forum.

Chontanawat, J. (2019). Modelling the Causal Relationship between Energy Consumption and Economic Growth in Asia. Working Paper. Bangkok, Thailand: KMU Technology

Dercon, S. (1993). Peasant Supply Response and Macroeconomic Policies: Cotton in Tanzania. Journal of African Economies, 2(2), 157-194.

Dickey, D., Jansen, D., and Thornton, D. (1991). A Primer on Cointegration With Application to Money and Income. Review, Federal Reserve Bank of St. Louis, 73(2), 58-78.

Dickey, D. A., and Fuller, W. A. (1981). Likelihood Ratio Statistics for Autoregressive Time Series with a UnitRroot. Econometrica: journal of the Econometric Society, 1057-1072.

Edwards, L., and Golub, S. S. (2004). South Africa's International Cost Competitiveness and Exports in Manufacturing. World Development, 32(8), 1323-1339. 
Elliott, G., Rothenberg, T. J., and James, H. (1996). Stock, 1996. Efficient Tests for an Autoregressive Rnit root. Econometrica, 64(4), 813-836.

Fang, W., Lai, Y., and Miller, S. M. (2006). Export Promotion through Exchange Rate Changes: Exchange Rate Depreciation or Stabilization? Southern Economic Journal, 611-626.

Food and Agriculture Organization (FAO) (2018). FAO database, Available Online [Accessed November 2018].

---. (2019). FAO Crop and Food Supply Assessement Mission to the Sudan. Special report, 2019.

Goldstein, M., and Khan, M. S. (1978). The Supply and Demand for Exports: A Simultaneous Approach. The review of economics and statistics, 275-286.

Granger, C. J. (1986). Developments in the Study of Cointegrated Economic Variables. Oxford Bulletin of Economics and statistics, 48(3), 213-228.

Granger, C. W. (1988). Some Recent Development in a Concept of causality. Journal of econometrics, 39(1-2), 199-211.

Granger, C. W., and Newbold, P. (1974). Spurious Regressions in Econometrics. Journal of econometrics, 2(2), 111-120.

Hannan, E. J., amd Quinn, B. G. (1979). The Determination of the Order of an Autoregression. Journal of the Royal Statistical Society: Series B (Methodological), 41(2), 190-195.

Islam, N., and Subramanian, A. (1989). Agricultural Exports of Developing Countries: Estimates of Income and Price Elasticities of Demand and Supply. Journal of Agricultural Economics, 40(2), 221-231.

Johansen, S. (1988). Statistical Analysis of Cointegration Vectors. Journal of Economic Dynamics and Control, $12(2-3), 231-254$.

Johansen, S., and Juselius, K. (1990). Maximum Likelihood Estimation and Inference on Cointegration with Applications to the Demand for Money. Oxford Bulletin of Economics and statistics, 52(2), 169-210.

Kingu, J. (2014). Determinants of Tanzanian Agricultural Export. Devolping Country Studies, 4(1), 91-104.

Kumar, N. R., and Rai, M. (2007). Performance, Competitiveness and Determinants of Tomato Export from India. Agricultural Economics Research Review, 20(2007), 551-562.

Lukonga, I. (1994). Nigeria's Non-Oil Exports; Determinants of Supply and Demand, 1970-1990. Working Paper. No 94/59.

Malik, N. (2010). Pakistan Agricultural Export Performance in the Light of Trade Liberalization and Economic Reforms. World Journal of Agricultural Sciences, 6(1), 29-38.

Ndulu, B. J., and Lipumba, N. H. (1990). International Trade and Economic Development in Tanzania. Trade and development in sub-Saharan Africa, Manchester University Press, Manchester.

Ngeno, N. K. (1996). Comparative Analysis of Economic Reform and Structural Adjustment Programs in Eastern Africa with Emphasis on Trade Policies. Development Experience Clearinghouse, USAID, 1-39.

Okoruwa, V. O., Ogundare, G., and Yusuf, S. (2003). Determinants of Traditional Tgricultural Exports in Nigeria: An Application of Cointegration and Correction Model. Quarterly Journal of International Agriculture, 42(4), 427-438.

Ranjan Kumar, N., Rai, A., and Rai, M. (2008). Export of Cucumber and Gherkin from India: Performance, Destinations, Competitiveness and Determinants. Agricultural Economics Research Review, 21(1), 130-138.

Schwarz, G. (1978). Estimating the Dimension of a Model. The Annals of Statistics, 6(2), 461-464.

Tijani, A. A., Ajetunmobi, O., and Ajobo, O. (1999). A Cointegration Approach to Nigeria's Cocoa Export Supply. Journal of Rural Economics and Development, 13(1), 45-56.

World Bank (2018), World Bank Database, Available Online [Accessed November 2018] 